\title{
Heat tolerance and physiological plasticity in the Antarctic collembolan, Cryptopygus antarcticus, and mite, Alaskozetes antarcticus
}

\author{
M. J. Everatt ${ }^{\mathrm{a}^{*}}$, P. Convey ${ }^{\mathrm{b}, \mathrm{c}}$, M. R. Worland ${ }^{\mathrm{b}}$, J. S. Bale ${ }^{\mathrm{a}}$ and S. A. L. Hayward ${ }^{\mathrm{a}}$ \\ ${ }^{a}$ School of Biosciences, University of Birmingham, Edgbaston, Birmingham B15 2TT, UK \\ ${ }^{b}$ British Antarctic Survey, Natural Environment Research Council, High Cross, Madingley Road, \\ Cambridge, CB3 OET, UK \\ ${ }^{c}$ National Antarctic Research Center, IPS Building, University Malaya, 50603 Kuala Lumpur, \\ Malaysia
}

*Corresponding author. Tel.: + 44789620 1770.Email address: mxe746@bham.ac.uk (M. J. Everatt).

\begin{abstract}
Polar amplification of global warming has led to an average $2^{\circ} \mathrm{C}$ rise in air temperatures in parts of the polar regions in the last 50 years. Poikilothermic ectotherms that are found in these regions, such as Collembola and mites, may therefore be put under pressure by changing environmental conditions. However, it has also been suggested that the thermal sensitivity of invertebrates declines with higher latitudes and, therefore, that polar ectotherms may not be at risk. In the current study, the heat tolerance and physiological plasticity to heat stress of two well-studied Antarctic invertebrates, the collembolan, Cryptopygus antarcticus, and the mite, Alaskozetes antarcticus, were investigated. Both species showed considerable heat tolerance, with each having an Upper Lethal Temperature (ULT) above $35^{\circ} \mathrm{C}$ ( 1 hour exposure). These species were also able to survive for over $43 \mathrm{~d}$ at $10^{\circ} \mathrm{C}$ and for periods of $5-20 \mathrm{~min}$ at $40^{\circ} \mathrm{C}$. Across all experimental procedures, A. antarcticus possessed a somewhat greater level of heat tolerance than C. antarcticus. Water loss during short duration exposures did not differ between the two species at 30,35 and $40^{\circ} \mathrm{C}$, suggesting that the greater tolerance of $A$. antarcticus over this timescale was not due to higher desiccation resistance. Physiological plasticity was investigated by testing for Rapid Heat Hardening (RHH) and long-term acclimation. RHH was observed to a small degree in both species at a warming rate of $0.5^{\circ} \mathrm{C} \min ^{-1}$, and also $0.2^{\circ} \mathrm{C} \mathrm{min}^{-1}$ in A. antarcticus alone. Longer-term acclimation (1 week at $10^{\circ} \mathrm{C}$ ) did not enhance the heat tolerance of either species. Even with this limited physiological plasticity, the results of this study indicate that $C$. antarcticus and A. antarcticus have capacity in their heat tolerance to cope with current and future environmental extremes of high temperature.
\end{abstract}

Keywords: Global warming, Rapid Heat Hardening, Acclimation, Thermal sensitivity, Invertebrate

\section{Introduction}

Over the last century, the mean surface temperature of the Earth has increased by $0.6^{\circ} \mathrm{C}$ (IPCC 2001). However, the rate of warming has been amplified at higher latitudes, with an average $2^{\circ} \mathrm{C}$ rise in parts of the polar regions in the last 50 years (Arctic Council 2005; Convey et al. 2009; Turner et al. 2009). The northern and western parts of the Antarctic Peninsula have been particularly affected; over the 
period 1951-2006, data from Vernadsky (Faraday) station in the Argentine Islands recorded an $0.53^{\circ} \mathrm{C}$ rise in temperature per decade. A further consequence of this warming at a global scale has been a decrease in snow and ice cover of over 10\% since the 1960s (Walther et al. 2002). These trends are set to continue, with general circulation models predicting further warming across the planet, and especially rapid warming in the polar regions.

Invertebrates are poikilothermic ectotherms, meaning that their body temperature is highly influenced by, and varies markedly with, the external environment (Speight et al. 2008). In essence, they are unable to regulate their body temperature as do birds and mammals, and are therefore susceptible to injuries, and developmental and reproductive impairment, resulting from temperature changes (Bale and Hayward 2010). Invertebrates can respond to these changes through alterations in their behaviour, phenology, physiology and genetic make-up, with these responses acting within or between generations (Lachenicht et al. 2010). Behaviourally, they can track favourable temperatures by moving towards either higher latitudes or altitudes (Walther et al. 2002; Sinclair et al. 2003; Gobbi et al. 2006). Several alpine spiders, for instance, have been shown to remain in their preferred temperature range by tracking the recession of the Forni Glacier in Italy (Gobbi et al. 2006). Invertebrates can also adapt behaviourally on a smaller scale, via microhabitat selection. Habitats, such as the Antarctic fellfields, are host to a diversity of microclimates and invertebrates select those which are the least stressful (Hodkinson et al. 1999; Holmstrup and Zachariassen 1996; Hoshikawa et al. 1988; Spaull 1973). Hayward et al. (2000, 2003, 2004) have gone on to show thermal and hygric preferences that are suggestive of this type of behavioural selection in a laboratory setting. A further response identified is a shift of spring and autumn phenology with the changing of the growing season (Ibanez et al. 2010; Walther et al. 2002).

Within generations, physiological adaptation is demonstrated through experimental acclimation or natural acclimatisation - permitting an organism to adapt to changing conditions via a change in form, movement or rate of physiological activity (Lachenicht et al. 2010). In the context of climate change, acclimatisation may involve the improvement of heat tolerance and upper thermal sub-lethal characteristics, such as physical activity, as temperatures rise. This form of adaptation has been shown in a number of organisms, including plants (Meyer and Santarius 1998), nematodes (Jagdale and Grewal 2003) and insects (Lachenicht et al. 2008). Over generations, invertebrates can adapt their physiology through the process of natural selection (Somero 2010).

The thermal sensitivity of terrestrial invertebrates to temperature change has been reported to decline from the tropics to the poles (Addo-Bediako et al. 2000; Deutsch et al. 2008). Some tropical species live very close to their upper thermal limits and, in some cases, at temperatures that exceed their physiological optima (Somero 2010). Polar species, in contrast, may live chronically below their temperature optima, and are suggested to have sufficient scope to tolerate higher temperatures. Warming might even help to alleviate the stress associated with low temperatures in the polar regions. Climate warming simulation studies using screens, solar domes and other controlled environmental systems (Bokhorst et al. 2008; Bale and Hayward 2010) suggest a rise in temperature will indeed lead to greater invertebrate numbers in Antarctic communities (Convey et al. 2002; Convey \& WynnWilliams 2002; Day et al. 2009). However, some manipulation studies also suggest the opposite outcome, with responses depending both on the detailed changes at micro-environmental level associated with the manipulation, and also on the group of invertebrates being considered (Convey et al. 2002, 2003; Bokhorst et al. 2011). Studies into upper thermal thresholds are also used in conjunction with climate manipulation studies and support the view that polar terrestrial invertebrates have low sensitivity to temperature change. Slabber et al. (2007), for example, showed that five Collembola species from a sub-Antarctic island, including Cryptopygus antarcticus, possessed Upper 
Lethal Temperatures (ULT $T_{50} \mathrm{~S}$ ) above $30^{\circ} \mathrm{C}$, far higher than the mean summer temperature in the Antarctic.

In the current study, the capacity of the collembolan, Cryptopygus antarcticus, and the mite, Alaskozetes antarcticus, to tolerate exposure to high temperatures was investigated, and their physiological plasticity to heat stress explored. In particular, this study addressed the ability of each species to respond to rapid increases in temperature, as might occur as a result of solar insolation of their microhabitats during diurnal cycles, and their tolerance to more prolonged exposures to high temperatures based on climate warming predictions. These species were selected as they represent two of the most successful arthropod groups in the maritime Antarctic and are considered 'model' organisms in polar research (Block and Convey 1995; Block et al. 2009), reaching numbers of up to $1.5 \times 10^{6}$ individuals $\mathrm{m}^{-2}$ (Burn 1986; Convey and Smith 1997; Tilbrook 1967). Consequently, any effect warming may have on them will likely be reflected throughout the community.

\section{Materials and methods}

\subsection{Invertebrate collection and storage conditions}

Naturally occurring summer-acclimatised individuals of $C$. antarcticus and A. antarcticus were collected from algae, moss and rocks on Léonie Island $\left(67^{\circ} \mathrm{S}, 68^{\circ} \mathrm{W}\right)$, near to the British Antarctic Survey's Rothera Research Station, Adelaide Island between January and March 2012. Samples were stored at $4^{\circ} \mathrm{C}$ (24:0 L:D) in plastic buckets containing substratum from the site of collection. For water loss experiments (sub-section 2.2.1.), samples were transported to the University of Birmingham under cool conditions ( 4 to $6^{\circ} \mathrm{C}$ ), taking approximately two months, before being stored at $4^{\circ} \mathrm{C}(0: 24$ $\mathrm{L}: \mathrm{D})$. All other experiments described were carried out at Rothera Research Station.

\subsection{Microhabitat temperatures}

The temperature range on Léonie Island on the soil surface underneath a rock was measured between 24 January and 12 March 2012. To illustrate the extremes of temperature potentially experienced by an animal on an exposed surface, temperature was also recorded every 5 min on a rock between 5 and 21 February 2012 at Rothera Research Station, using a Tinytag Transit 2 Datalogger (Gemini Data Loggers, Chichester, UK). Data were uploaded using Tinytag Explorer Software (Gemini Data Loggers, Chichester, UK).

\subsection{Upper Lethal Temperatures (ULTs)}

The upper temperature at which invertebrates no longer survived was determined by warming individuals of C. antarcticus and A. antarcticus at $0.2^{\circ} \mathrm{C} \mathrm{min}^{-1}$ from $4^{\circ} \mathrm{C}$ to progressively higher temperatures (30 to $37^{\circ} \mathrm{C}$ for C. antarcticus and 30 to $40^{\circ} \mathrm{C}$ for A. antarcticus). Individuals were subsequently held at the target temperature for $1 \mathrm{~h}$, before being cooled back to $4^{\circ} \mathrm{C}$ at the same rate. Three replicates of 10 individuals of each species were placed in Eppendorf tubes, which were packed inside glass test tubes plugged with sponge and placed in an alcohol bath (Haake Phoenix II C50P, Thermo Electron Corporation), prior to each experimental treatment. Control groups were handled, and exposed, in the same way at $4^{\circ} \mathrm{C}$. The temperature experienced by the invertebrate was measured by placing a thermocouple within an identical Eppendorf tube into one of the glass test tubes. At the end of experimental treatments, individuals were rapidly transferred (over ice) from the Eppendorf tubes into plastic universal tubes containing moist Plaster of Paris, and returned to the rearing conditions $\left(4^{\circ} \mathrm{C}, 0: 24 \mathrm{~L}: \mathrm{D}\right)$. Survival, defined by individuals moving either spontaneously or in response to gentle contact stimulus, was assessed 24 and $72 \mathrm{~h}$ after treatment. Replicate collection, 
controls, thermocouple use, recovery and survival assessment were the same for all following experimental procedures unless stated otherwise.

\subsubsection{Water loss following high temperature exposure}

For both species, five replicates of 10 individuals were exposed to three temperatures (30, 35 and $40^{\circ} \mathrm{C}$ ) as described in sub-section 2.2. Individuals were weighed prior to and upon removal from each treatment, then following drying to constant mass at $60^{\circ} \mathrm{C}$ for $24 \mathrm{~h}$. From these values, initial water content and percentage water loss or gain were calculated (cf. Hayward et al. 2007).

\subsection{Rapid Heat Hardening (RHH)}

\subsubsection{Determination of the discriminating temperature}

In rapid cold and heat hardening experiments the discriminating temperature is defined as the temperature at which there is $10-20 \%$ survival after an exposure time of e.g. 1 h (Lee et al. 1987). This temperature was determined here by exposing individuals (three replicates of 10 individuals) of C. antarcticus and $A$. antarcticus directly (i.e. without ramping from $4^{\circ} \mathrm{C}$ ) to progressively higher temperatures (30 to $36^{\circ} \mathrm{C}$ for C. antarcticus and 36 to $40^{\circ} \mathrm{C}$ for A. antarcticus) for $1 \mathrm{~h}$, before returning to the rearing temperature $\left(4^{\circ} \mathrm{C}\right)$ at $0.2^{\circ} \mathrm{C} \mathrm{min}^{-1}$.

\subsubsection{Induction of $R H H$}

To investigate the RHH response, individuals of C. antarcticus and A. antarcticus (3 replicates of 10 individuals for each species) were warmed to the discriminating temperature at three different rates $\left(0.5^{\circ} \mathrm{C} \min ^{-1}, 0.2^{\circ} \mathrm{C} \min ^{-1}\right.$ and $\left.0.1^{\circ} \mathrm{C} \min ^{-1}\right)$. As before, individuals were held for $1 \mathrm{~h}$ at the discriminating temperature and then cooled back to the rearing temperature $\left(4^{\circ} \mathrm{C}\right)$ at $0.2^{\circ} \mathrm{C} \min ^{-1}$.

\subsection{Long-term heat tolerance}

Five replicates of 10 individuals of $C$. antarcticus and $A$. antarcticus were transferred to either 4 or $10^{\circ} \mathrm{C}$ for up to $49 \mathrm{~d}$. Individuals were held in universal tubes with a base of moist Plaster of Paris and a small amount of substratum within an incubator. Survival was assessed every $7 \mathrm{~d}$ for the first four weeks and then every $3 \mathrm{~d}$ thereafter. The temperature inside the incubator was measured using a Tinytag Transit 2 Datalogger.

\subsection{Acute heat exposure}

Three replicates of 10 individuals of $C$. antarcticus and $A$. antarcticus were exposed directly to three temperatures: 40,45 and $50^{\circ} \mathrm{C}$. At each temperature, individuals were held for 5, 10 or $20 \mathrm{~min}$. Following high temperature treatment, they were transferred directly to recovery conditions $\left(4^{\circ} \mathrm{C}\right.$, 24:0 L:D).

\subsection{Effect of acclimation on heat tolerance}

Stock cultures of $C$. antarcticus and A. antarcticus were held for one week at $10^{\circ} \mathrm{C}$ prior to experimental treatments. Three replicates of 10 individuals of each species were subsequently warmed at $0.2^{\circ} \mathrm{C} \min ^{-1}$ to three temperatures $\left(33,34\right.$ and $35^{\circ} \mathrm{C}$ for $C$. antarcticus and $39,39.5$ and $40^{\circ} \mathrm{C}$ for $A$. antarcticus), and held there for $1 \mathrm{~h}$, before being cooled to the rearing temperature $\left(4^{\circ} \mathrm{C}\right)$ at $0.2^{\circ} \mathrm{C} \min ^{-}$ 1 .

\subsection{Statistical analysis}


The Kolmogorov-Smirnov test was used to check for normal distribution of survival and percentage water loss data. Normally distributed data were analysed using analysis of variance (ANOVA) and Tukey's multiple range test; data that were not normally distributed were analysed using the KruskalWallis test.

\section{Results}

\subsection{Microhabitat temperatures}

Soil surface temperatures beneath a rock on Léonie Island ranged from 13.5 to $-6.1^{\circ} \mathrm{C}$, and averaged $1.9^{\circ} \mathrm{C}$, between 24 January and 12 March 2012 (Fig. 1), whereas the temperature on the rock surface ranged between 31.2 and $-8.7^{\circ} \mathrm{C}$ (Fig. 2). The diurnal temperature range on the rock surface was high, regularly exceeding $20^{\circ} \mathrm{C}$ (with temperature changing at rates $>2.5^{\circ} \mathrm{C} / \mathrm{h}$ ), and on seven occasions the temperature ranged from below $0^{\circ} \mathrm{C}$ to above $20^{\circ} \mathrm{C}$ within $12 \mathrm{~h}$.

\subsection{Upper Lethal Temperatures (ULTs)}

Survival declined dramatically at temperatures close to the ULT for both species (Fig. 3). After $1 \mathrm{~h}$ at $34^{\circ} \mathrm{C}$, almost $90 \%$ of C. antarcticus survived, while only $3 \%$ survived $1 \mathrm{~h}$ at $36^{\circ} \mathrm{C}$, and none survived at $37^{\circ} \mathrm{C}$. Alaskozetes antarcticus had greater heat tolerance than C. antarcticus, with $100 \%$ survival of $1 \mathrm{~h}$ at $37^{\circ} \mathrm{C}, 81 \%$ survival at $39^{\circ} \mathrm{C}$, but $0 \%$ survival at $40^{\circ} \mathrm{C}$. The difference between species was not significant at 35,36 and $37^{\circ} \mathrm{C}$, according to the Kruskal-Wallis test ( $P>0.05$ Kruskal-Wallis test).

\subsubsection{Water loss following high temperature exposure}

Water loss was minimal following a $1 \mathrm{~h}$ exposure to 30,35 and $40^{\circ} \mathrm{C}$ in both species (Table 1). The amount lost did not differ significantly from the control $\left(1 \mathrm{~h}\right.$ at $\left.4^{\circ} \mathrm{C}\right)$ in all treatments, except for a $1 \mathrm{~h}$ exposure at $40^{\circ} \mathrm{C}$ in $C$. antarcticus ( $P<0.05$ Tukey's multiple range test). There was no significant difference between the amount of water lost in C. antarcticus and A. antarcticus across each of the three treatments $(P>0.05$ Tukey's multiple range test).

\subsection{Rapid Heat Hardening (RHH)}

\subsubsection{Determination of the discriminating temperature}

The discriminating temperature was determined to be $35^{\circ} \mathrm{C}$ for $C$. antarcticus ( $10 \%$ survival), and $39.5^{\circ} \mathrm{C}$ for $\mathrm{A}$. antarcticus, a temperature which although resulting in $0 \%$ survival, was chosen because it was closer to the $10-20 \%$ survival required than the $37 \%$ value obtained at $39^{\circ} \mathrm{C}$ (Fig. 4).

\subsubsection{RHH induction}

In both species, all three warming treatments $\left(0.5,0.2\right.$ and $\left.0.1^{\circ} \mathrm{C} \mathrm{min}^{-1}\right)$ gave greater survival compared to direct exposure to the discriminating temperature (Fig. 5). The increase in survivorship was significant for $0.5^{\circ} \mathrm{C} \mathrm{min}{ }^{-1}$ in C. antarcticus ( $P<0.05$ Tukey's multiple range test), and for 0.5 and $0.2^{\circ} \mathrm{C} \mathrm{min}{ }^{-1}$ in $A$. antarcticus ( $P<0.05$ Tukey's multiple range test). For $A$. antarcticus, survival declined as the rate of warming was lowered, from $73 \%$ at $0.5^{\circ} \mathrm{C} \min ^{-1}$ to $30 \%$ at $0.1^{\circ} \mathrm{C} \mathrm{min}^{-1}$. The rate of $0.5^{\circ} \mathrm{C} \mathrm{min}{ }^{-1}$ also gave the greatest survival in C. antarcticus.

\subsection{Long-term heat tolerance}

C. antarcticus was more susceptible at both 4 and $10^{\circ} \mathrm{C}$ than A. antarcticus (Fig. 6). Survival of $C$. antarcticus decreased significantly at $4{ }^{\circ} \mathrm{C}$ to $70 \%$ after $46 \mathrm{~d}(P<0.05$ Tukey's multiple range test), 
and to $0 \%$ at $10^{\circ} \mathrm{C}(P<0.05$ Kruskal-Wallis test) (Fig. 6). Alaskozetes antarcticus survival also decreased significantly at $10^{\circ} \mathrm{C}(P<0.05$ one-way ANOVA), but only to $63 \%$ after $49 \mathrm{~d}$, and was not significantly different at $4^{\circ} \mathrm{C}$ (80\% survival, $P>0.05$ Kruskal-Wallis test).

\subsection{Acute heat exposure}

At $40^{\circ} \mathrm{C}$, A. antarcticus outperformed C. antarcticus in all treatments (5, 10 and 20 min, Fig. 7), but this was not significant ( $P>0.05$ Mann-Whitney U test; one-way ANOVA). At 45 and $50^{\circ} \mathrm{C}$, both $C$. antarcticus and A. antarcticus survived poorly (Fig. 7).

\subsection{Effect of acclimation on heat tolerance}

Acclimation at $10^{\circ} \mathrm{C}$ did not significantly enhance the heat tolerance of $C$. antarcticus or $A$. antarcticus at any of the temperatures tested $(P>0.05$ Mann-Whitney U test; one-way ANOVA, Fig. 8).

\section{Discussion}

The Antarctic environment is unable to support large biological communities and, in extreme cases, may only support a food web of less than five animal species (Block et al. 2009; Hodgson et al. 2010). The few terrestrial invertebrates that inhabit these communities play an important role in processes such as soil conditioning and nutrient cycling (Bokhorst et al. 2007). In contrast to the temperate and tropical regions, which have greater species diversity and subsequently greater functional redundancy, polar communities will struggle to compensate for the loss of species and their associated services. Changing environmental conditions as a result of climate warming may put pressure on polar species. However, the thermal sensitivity of polar invertebrates to temperature increase has been suggested to be low, and warming may even result in more optimal conditions and a reduction in environmental constraints on invertebrate physiology (Addo-Bediako et al. 2000; Convey et al. 2009; Deutsch et al. 2008). The acute and chronic tolerances, as well as the physiological plasticity, of the collembolan, C. antarcticus, and the mite, A. antarcticus, are discussed here in the context of their ability to respond to climate warming.

\subsection{Basal heat tolerance}

The collembolan, $C$. antarcticus, and the mite, A. antarcticus, demonstrated considerable heat tolerance, with each having a ULT of over $35^{\circ} \mathrm{C}$ (Fig. 3). In two sub-Antarctic studies on Marion Island (Deere et al. 2006; Slabber et al. 2007) and one study at Cape Hallet, North Victoria Land (Sinclair et al. 2006), several mites and Collembola, including C. antarcticus on Marion Island, were also shown to possess ULTs above $30^{\circ} \mathrm{C}$. While this level of tolerance is somewhat lower than found in temperate or tropical species, such as the Asian brown planthopper, Nilaparvata lugens, which has a $\mathrm{ULT}_{50}$ of 41.8 to $42.5^{\circ} \mathrm{C}$ (Piyaphongkul et al. 2012), this nevertheless demonstrates a considerable capacity to cope with current conditions (Convey 1996a). Indeed ULTs above $35^{\circ} \mathrm{C}$ are high when considering the temperatures these Antarctic species typically experience during the summer. Tinytag measurements on Léonie Island through February and March did not show surface temperatures exceeding $15^{\circ} \mathrm{C}$ (Fig. 1). Likewise, temperatures recorded between 2002 and 2008 on nearby Anchorage Island did not rise higher than $20^{\circ} \mathrm{C}$. However, it should be noted that diurnal fluctuations in some microhabitats and years can exceed $30^{\circ} \mathrm{C}$ for short periods of minutes to hours (Fig. 3; Smith 1988; Convey 1996a). Both C. antarcticus and A. antarcticus were also able to survive for over $43 \mathrm{~d}$ at $10^{\circ} \mathrm{C}$ (Fig. 6) and showed survival at $40^{\circ} \mathrm{C}$ over periods of 5-20 min (Fig. 7). These two species are 
therefore well adapted to survive the summer on Léonie Island and have some capacity to tolerate higher temperatures than those that are currently experienced (Day et al. 2009; Convey et al. 2009).

Survival alone is not an accurate measure of fitness. Success is also influenced by the sub-lethal characteristics of a species, such as the effects of heat stress on reproduction and development. In many species, survival is possible at extremes of temperature, but they are then unable to fully develop and reproduce once usual temperatures are restored (Shreve et al. 2004). Invertebrates are also hampered during temperature extremes (Piyaphongkul et al. 2012; Powell and Bale 2006; Shreve et al. 2004; Wang and Kang 2003). Uncoordinated movement $72 \mathrm{~h}$ after high temperature treatment in the current study $\left(>30^{\circ} \mathrm{C}\right.$, data not shown) indicates that permanent damage might have been incurred as a result of high temperature exposure, which could subsequently result in impaired development and reproduction. Thus, whilst $C$. antarcticus and A. antarcticus can survive above $35^{\circ} \mathrm{C}$, negative effects on them and their communities might be seen at much lower temperatures.

\subsection{Interspecific comparisons}

Alaskozetes antarcticus showed significantly greater heat tolerance than $C$. antarcticus. This capacity was demonstrated across all experimental procedures; A. antarcticus had a higher ULT (Fig. 3), exhibited higher survival of acute heat exposure (Fig. 7) and survived for longer at $10^{\circ} \mathrm{C}$ (Fig. 6). Previous studies also show that mite species tend to have higher heat tolerance than Collembola (Deere et al. 2006; Sinclair et al. 2006). It was initially hypothesised that higher desiccation resistance accounted for the greater heat tolerance in A. antarcticus. This is because C. antarcticus is a hygric species, with little or no control of water loss (Convey et al. 2003; Worland and Block 1986, 2003), whereas A. antarcticus is a mesic species and has good control over its water content (Benoit et al. 2007; Worland and Block 1986). However, there was little difference in water loss with temperature and no significant difference in the water lost between the two species over the experimental durations under all temperature treatments (Table 1). It seems, therefore, that A. antarcticus possesses a more adaptive heat tolerance physiology than $C$. antarcticus. Possible physiological adaptations capable of operating over these experimental timescales include the activation of heat shock proteins (Schill et al. 2004; Rinehart et al. 2006; Michaud et al. 2008) and membrane remodelling (Hazel 1995).

The results of this study suggest that, in a rapidly warming Antarctic, A. antarcticus would have some advantage over $C$. antarcticus. Climate manipulation studies also suggest that mites will be favoured over Collembola under warming. In both the Arctic (Coulson et al. 1996) and the Antarctic (Bokhorst et al. 2008; Convey et al. 2002), Collembola numbers decreased significantly under artificially warmed conditions over three years, while mite numbers remained largely unchanged. However, Webb et al. (1998) proposed that oribatid mite populations are slow to show a response to short-term environmental changes and that manipulations longer than those used in the aforementioned studies are required to identify any effect. A further consideration is how the heat tolerance of these species relates to their behaviour. Collembola are more mobile than oribatid mites, and so may be better able to relocate to habitats in their preferred temperature range. Consequently, the more rapid movement of C. antarcticus could compensate for reduced heat tolerance in this species. It is therefore only in a uniform thermal environment where A. antarcticus would be favoured (see also Hayward et al. 2003).

\subsection{Physiological plasticity}

The Antarctic hosts a diversity of microclimates. In some of these, the daily temperature can fluctuate by as much as $50^{\circ} \mathrm{C}$ (Convey 1996a). In the current study, measurements on a rock surface showed temperature variation approaching or exceeding $30^{\circ} \mathrm{C}$ on a diurnal timescale (Fig. 2). Similar patterns 
have been reported in other microhabitats; temperatures within the moss cushion, Schistidium antarctici, were shown to cycle between $-9.2^{\circ} \mathrm{C}$ and $42.8^{\circ} \mathrm{C}$ over $24 \mathrm{~h}$ (Smith 1988). It could, therefore, be to an invertebrate's advantage to adapt quickly to changes in temperature. One means of tracking temperature changes is via a process termed Rapid Heat Hardening (RHH), which is the rapid induction of heat tolerance over minutes to hours (Benoit et al. 2009). Both C. antarcticus and A. antarcticus showed evidence of $\mathrm{RHH}$, with enhanced survival at their discriminating temperatures following warming at the three rates of $0.1,0.2$ and $0.5^{\circ} \mathrm{C} \mathrm{min}^{-1}$ (Fig. 5). The rate of $0.5^{\circ} \mathrm{C} \mathrm{min}{ }^{-1}$ gave the greatest increase in survival for both species, and was likely due to the reduced time spent at harmful temperatures. Overall, the RHH response was small, however, giving an average rise in survivorship of only 38\% across all treatments. It is possible that RHH has more of an influence on the sub-lethal characteristics of C. antarcticus and A. antarcticus. Although there is as yet little support for this occurring in other species, there is ample evidence of a sub-lethal influence during Rapid Cold Hardening (RCH) (Denlinger and Lee 2010). For example, courting, reproduction, and the Critical Thermal minimum (CTmin - loss of coordination at low temperatures) were all improved in D. melanogaster following RCH (Shreve et al. 2004; Kelty and Lee 1999).

Physiological plasticity can also be seen over longer timescales in the form of experimental acclimation (Lachenicht et al. 2010). The nematodes, Steinernema carpocapsae and Steinernema feltiae, for instance, showed enhanced heat tolerance, and higher virulence under heat stress, when reared at higher, and thus acclimatory, temperatures (Jagdale and Grewal 2002). Similarly, heightened heat tolerance following time at higher rearing temperatures was exhibited in both marine and terrestrial mites found on Marion Island (Deere et al. 2006). In the current study, a one week acclimation at $10^{\circ} \mathrm{C}$ had no significant impact on survivorship in either C. antarcticus or $A$. antarcticus (Fig. 8). A null response in the sub-Antarctic collembolan Tullbergia bisetosa, and a decline in heat tolerance in C. antarcticus, was also shown following acclimation at $15^{\circ} \mathrm{C}$ (Slabber et al. 2007).

Physiological plasticity across generations may also be important; species with sufficient genetic variation that produce progeny with higher physiological thermal optima may end up as the 'winners' in scenarios of climate warming (Somero 2010). In a number of species, life at low temperatures has resulted in the loss of physiology suited to warming conditions (Somero 2010). The polar marine ectotherms of the Southern Ocean provide a particularly good illustration. These species are stenothermal and have experienced a narrow range of low temperatures for millions of years (at present -1.9 to $+1.8^{\circ} \mathrm{C}$ or much less) (Somero 2010). As a result, many have lost their ability to initiate a heat shock response (Clark et al. 2009). The same might be true of polar terrestrial invertebrates with regard to their physiological plasticity, and if so these will therefore become less successful as climate change intensifies. However, it has also been suggested that the greater thermal variability typical of polar terrestrial environments will preserve heat tolerance adaptation (Peck et al. 2006). Indeed, the climatic variability hypothesis (Stevens 1989) suggests that the greater thermal variability at higher latitudes means that invertebrates must have a greater physiological range and subsequently retain physiological plasticity at higher temperatures. Also of note are the long generation times of these animals, which frequently extend to five years or more, and therefore limit their ability to adapt across generations (Convey 1994, 1996b).

\section{Conclusion}

It has been suggested that the thermal sensitivity of invertebrates to temperature change decreases from the tropics to the poles (Deutsch et al. 2008). This statement is supported by the current study, which shows that both $C$. antarcticus and $A$. antarcticus have scope with which to tolerate current and 
future conditions. Warming may even alleviate the stresses experienced by these invertebrates and provide an opportunity for population growth. If these species are assumed to be characteristic of other Collembola and Acari in the maritime Antarctic, a positive impact on the community and on ecosystem functions such as nutrient cycling, may also be seen.

\section{Acknowledgements}

MJE was funded by the Natural Environment Research Council (RRBN15266) and was supported by the British Antarctic Survey and the University of Birmingham. We thank Sharon Duggan (BAS) for help in the location of sample sites. This paper contributes to the BAS 'Polar Science for Planet Earth' and SCAR 'Evolution and Biodiversity in Antarctica' research programmes.

\section{References}

Addo-Bediako, A., Chown, S. L. and Gaston, K. J. ( 2000 ) Thermal tolerance, climatic variability and latitude. Proceedings of the Royal Society of London B. 267, 739-745 .

Arctic Council (2005) Arctic climate impact assessment - scientific report. Cambridge: Cambridge University Press, 1046 pp (available at http://www.acia.uaf.edu/pages/scientific.html).

Bale, J. S. and Hayward, S. A. L. (2010) Insect overwintering in a changing climate. The Journal of Experimental Biology. 213, 980-994.

Benoit, J. B., Lopez-Martinez, G., Teets, N. M., Phillips, S. A. and Denlinger, D. L. (2009) Responses of the bed bug, Cimex lectularius, to temperature extremes and dehydration: levels of tolerance, rapid cold hardening and expression of heat shock proteins. Medical and Veterinary Entomology. 23 (4), 418-425.

Benoit, J. B., Yoder, J. A., Lopez-Martinez, G., Elnitsky, M. A., Lee, R. E. and Denlinger, D. L. (2007) Adaptations for the maintenance of water balance by three species of Antarctic mites. 31 (5), 539-547.

Block, W. and Convey, P., 1995. The biology, life cycle and ecophysiology of the Antarctic mite Alaskozetes antarcticus. Journal of the Zoological Society of London. 236, 431-449.

Block, W., Smith, R. I. L. and Kennedy, A. D. (2009) Strategies of survival and resource exploitation in the Antarctic fellfield ecosystem. Biological Reviews of the Cambridge Philosophical Society. 84 (3), 449-84.

Bokhorst, S., Huiskes, A., Convey, P., Sinclair, B. J., Lebouvier, M., Van de Vijver, B. and Wall, D. H. (2011) Microclimate impacts of passive warming methods in Antarctica: implications for climate change studies. Polar Biology. 34 (10), 1421-1435.

Bokhorst, S., Huiskes, A., Convey, P., van Bodegom, P.M. and Aerts, R. (2008) Climate change effects on soil arthropod communities from the Falkland Islands and the Maritime Antarctic. Soil Biology and Biochemistry. 40 (7), 1547-1556.

Burn, A. (1986) Feeding rates of the cryptostigmatid mite Alaskozetes antarcticus (Michael). British Antarctic Survey Bulletin. 71, 11-17.

Clark, M. S., Fraser, K. P. P. and Peck, L. S. (2009) Lack of an HSP70 heat shock response in two Antarctic marine invertebrates. Polar Biology. 31, 1059-1065.

Convey, P. and Smith, R. I. L. (1997) The terrestrial arthropod fauna and its habitats in northern Maguerite Bay and Alexander Island, maritime Antarctic. Antarctic Science 9, 12-26.

Convey, P and Wynn-Williams, D. D. (2002) Antarctic soil nematode response to artificial climate amelioration. European Journal of Soil Biology. 38, 255-259.

Convey, P., Bindschadler, R., di Prisco, G., Fahrbach, E., Gutt, J., Hodgson, D. A., Mayewski, P. A., Summerhayes, C.P. and Turner, J. (2009) Antarctic climate change and the environment. Antarctic Science. 21 (6), 541-563.

Convey, P., Block, W. and Peat, H. J. (2003) Soil arthropods as indicators of water stress in Antarctic terrestrial habitats? Global Change Biology. 9, 718-730. 
Convey, P. (1994) Growth and survival strategy of the Antarctic mite Alaskozetes antarcticus. Ecography. 17, 97-107.

Convey, P. (1996a) Overwintering strategies of terrestrial invertebrates in Antarctica - the significance of flexibility in extremely seasonal environments. European Journal of Entomology. 93, 489-505.

Convey, P. (1996b) The influence of environmental characteristics on life history attributes of Antarctic terrestrial biota. Biological Reviews. 71, 191-225.

Convey, P., Pugh, P. J. A., Jackson, C., Murray, A. W., Ruhland, C. T., Xiong, F. S. and Day, A. (2002) Response of Antarctic Terrestrial Microarthropods to Long-Term Climate Manipulations. Ecology. 83 (11), 3130-3140.

Coulson, S. J., Hodkinson, I. D., Webb, N. R., Block, W., Bale, J. S., Strathdee, A. T., Worland, M. R. and Wooley, C. (1996) Effects of experimental temperature elevation on high-arctic soil microarthropod populations. Polar Biology. 16 (2), 147-153.

Day, T. A., Ruhland, C. T., Strauss, S. L., Park, J., Krieg, M. L., Krna, M. A. and Bryant, D. M. (2009) Response of plants and the dominant microarthropod, Cryptopygus antarcticus, to warming and contrasting precipitation regimes in Antarctic tundra. Global Change Biology. 15 (7), 1640-1651.

Denlinger, D. L. and Lee, R. E. (2010) Rapid cold-hardening: Ecological significance and underpinning mechanisms. In: Low Temperature Biology of Insects (Ed. by D. L. Denlinger and R. E. Lee), pp 35-58. Cambridge University Press.

Deutsch, C. A., Tewksbury, J. J., Huey, R. B., Sheldon, K. S., Ghalambor, C. K., Haak, David C. and Martin, P. R. (2008) Impacts of climate warming on terrestrial ectotherms across latitude Thermal Safety margin. Proceedings of the National Academy of Sciences. 105 (18), 66686672.

Gobbi, M., Fontaneto, D. and De Bernardi, F. (2006) Influence of climate changes on animal communities in space and time: the case of spider assemblages along an alpine glacier foreland. Global Change Biology. 12 (10), 1985-1992.

Hayward, S. A. L., Rinehart, J. P., Sandro, L. H., Lee, R. E. and Denlinger, D. L. (2007) Slow dehydration promotes desiccation and freeze tolerance in the Antarctic midge Belgica antarctica. The Journal of Experimental Biology. 210, 836-844.

Hayward, S. A. L., Worland, M. R., Bale, J. S. and Convey, P. (2000) Temperature and the hygropreference of the Arctic Collembolan Onychiurus arcticus and mite Lauroppia translamellata. Physiological Entomology. 25 (3), 266-272.

Hayward, S. A. L., Worland, M. R., Convey, P. and Bale, J. S. (2004) Habitat moisture availability and the local distribution of the Antarctic Collembola Cryptopygus antarcticus and Friesea grisea. Soil Biology and Biochemistry. 36 (6), 927-934.

Hayward, S. A. L., Worland, M. R., Convey, P. and Bale, J. S. (2003) Temperature preferences of the mite, Alaskozetes antarcticus, and the collembolan, Cryptopygus antarcticus from the maritime Antarctic. Physiological Entomology. 28 (2), 114-121.

Hazel, J. R. (1995) Thermal adaptation in biological membranes: is homeoviscous adaptation the explanation?. Annual Review of Physiology. 57 (94), 19-42.

Hodgson, D., Convey, P., Verleyen, E., Vyverman, W., McInnes, S., Sands, C. S., Fernández-Carazo, R. and Wilmotte, A (2010) Observations on the limnology and biology of the Dufek Massif, Transantarctic Mountains $82^{\circ}$ South. Polar Science. 4, 197-214.

Hodkinson, I. D., Webb, N. R., Bale, J. S. and Block, W. (1999) Hydrology, water availability and tundra ecosystem function in a changing climate: the need for a closer integration of ideas?. Global Change Biology. 5 (3), 359-369.

Holmstrup, M. and Zachariassen, K. E. (1996) Physiology of cold hardiness in earthworms. Comparative Biochemistry and Physiology Part A: Physiology. 115 (2), 91-101.

Hoshikawa, K., Tsutsui, H., Honma, K. and Sakagami, S. F. (1988) Cold resistance in four species of beetles overwintering in the soil, with notes on the overwintering strategies of some soil insects. Applied Entomological Zoology. 23, 273-281. 
Ibanez, I., Primack, R. B., Miller-Rushing, A. J., Ellwood, E., Higuchi, H., Lee, S. D., Kobori, H. and Silander, J. A. (2010) Forecasting phenology under global warming. Philosophical Transactions of the Royal Society B. 365 (1555), 3247-3260.

IPCC (2001) Summary for policymarker, Climate change 2001: Impacts, adaptations and vulnerability. Sixth session of IPCC (Inter- governmental Panel on Climate Change) Working Group II, Geneva, Switzerland, 13-16 February 2001.

Jagdale, G. B. and Grewal, P. S. (2003) Acclimation of entomopathogenic nematodes to novel temperatures: trehalose accumulation and the acquisition of thermotolerance. International Journal for Parasitology. 33 (2), 145-152.

Kelty, J. D. and Lee, R. E. (1999) Induction of rapid cold hardening by cooling at ecologically relevant rates in Drosophila melanogaster. Journal of Insect Physiology. 45 (8), 719-26.

Lachenicht, M. W., Clusella-Trullas, S., Boardman, L., Le Roux, C. and Terblanche, J. S. (2010) Effects of acclimation temperature on thermal tolerance, locomotion performance and respiratory metabolism in Acheta domesticus L. (Orthoptera: Gryllidae). Journal of Insect Physiology. 56 (7), 822-830.

Lee, R. E., Chen, C. P. and Denlinger, D. L. (1987) A rapid cold-hardening process in insects. Science (New York, N.Y.). 238 (4832), 1415-17.

Meyer, H. and Santarius, K. (1998) Short-term thermal acclimation and heat tolerance of gametophytes of mosses. Oecologia. 115, 1-8.

Michaud, M. R., Benoit, J. B., Lopez-Martinez, G., Elnitsky, M. A., Lee, R. E. and Denlinger, D. L. (2008). Metabolomics reveals unique and shared metabolic changes in response to heat shock, freezing, and desiccation in the Antarctic midge, Belgica antarctica. Journal of Insect Physiology. 54, 645-655.

Peck, L. S., Convey, P. and Barnes, D. K. A. (2006) Environmental constraints on life histories in Antarctic ecosystems: tempos, timings and predictability. Biological Reviews, 81, 75-109.

Piyaphongkul, J., Pritchard, J. P. and Bale, J. S. (2012) Can tropical insects stand the heat? A case study with the brown planthopper Nilaparvata lugens (Stål). PloS ONE. 7 (1), e29409.

Powell, S. J. and Bale, J. S. (2006) Effect of long-term and rapid cold hardening on the cold torpor temperature of an aphid. Physiological Entomology. 31 (4), 348-352.

Rinehart, J. P., Hayward, S. A. L., Elnitsky, M. A., Sandro, L. H., Lee, R. E. and Denlinger, D. L. (2006) Continuous up-regulation of heat shock proteins in larvae, but not adults, of a polar insect. Proceedings of the National Academy of Sciences of the United States of America. 103 (38), 14223-7.

Schill, R., Steinbruck, G. and Kohler, H. (2004) Stress gene (hsp70) sequences and quantitative expression in Milnesium tardigradum (Tardigrada) during active and cryptobiotic stages. Journal of Experimental Biology. 207, 1607-1613.

Shreve, S. M., Kelty, J. D. and Lee, R. E. (2004) Preservation of reproductive behaviors during modest cooling: rapid cold-hardening fine-tunes organismal response. Journal of Experimental Biology. 207 (11), 1797-1802.

Sinclair, B. J., Vernon, P., Klok, C. J. and Chown, S. L. (2003) Insects at low temperatures: an ecological perspective. Trends in Ecology and Evolution. 18 (5), 257-262.

Slabber, S., Worland, M. R., Leinaas, H. P. and Chown, S. L. (2007) Acclimation effects on thermal tolerances of springtails from sub-Antarctic Marion Island: indigenous and invasive species. Journal of Insect Physiology. 53 (2), 113-125.

Smith, R. I. L. (1988) Recording bryophyte microclimate in remote and severe environments. In: Methods in Bryology (ed. J. M. Glime), pages 275-284. Hattori Botanical Laboratory, Nichinan, Miyazaki, Japan.

Somero, G. (2010) The physiology of climate change: how potentials for acclimatization and genetic adaptation will determine 'winners' and 'losers'. The Journal of Experimental Biology. 213 (6), 912-920.

Spaull, V. W. (1973) Qualitative and quantitative distribution of soil nematodes of Signy Island, South Orkney Islands. British Antarctic Survey Bulletin. 34, 177-184. 
Speight, M. R., Hunter, M. D. and Watt, A. D. (2008) Insects and climate. In: Ecology of Insects Concepts and Applications (ed. by M. R. Speight, M. D. Hunter and A. D. Watt), pp 33-60. Wiley-Blackwell.

Stevens, G. C. 1989 The latitudinal gradient in geographical range: how so many species coexist in the tropics. American Naturalist. 133, 240-256.

Tilbrook, P.J. (1967). Arthropod ecology in the maritime Antarctic. Antarctic Research Service. 10, 331-356.

Turner, J., Bindschadler, R., Convey, P., Di Prisco, G., Fahrbach, E., Gutt, J., Hodgson, D. A., Mayewski, P. A. and Summerhayes, C. P. eds. (2009). Antarctic climate change and the environment. Cambridge: Scientific Committee for Antarctic Research, 554 pp.

Walther, G., Post, E., Convey, P., Menzel, A., Parmesank, C., Beebee, T. J. C., Fromentin, J. I., Ove, H. and Bairlein, F. (2002) Ecological responses to recent climate change. Nature. 416, 389395.

Wang, X-H. and Kang, L. (2003) Rapid cold hardening in young hoppers of the migratory locust Locusta migratoria L. (Orthoptera: Acridiidae). Cryoletters. 24 (5), 331-40.

Webb, N. R., Coulson, S. J., Hodkinson, I. D., Block, W., Bale, J. S., Strathdee, A. T., (1998) The effects of experimental temperature elevation on populations of cryptostigmatic mites in high Arctic soils. Pedobiologia. 42, 298-308.

Worland, M. R. and Block, W. (1986) Survival and water loss in some Antarctic arthropods. Journal of Insect Physiology. 32, 579-584.

Worland, R. and Block, W. (2003) Desiccation stress at sub-zero temperatures in polar terrestrial arthropods. Journal of Insect Physiology. 49 (3), 193-203.

\section{7}

8

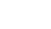

0

1

2

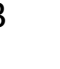

5


521

522

523 


\section{Figure and Table legends}

Fig. 1. Surface temperature beneath a rock on Léonie Island, near Rothera Research Station, Adelaide Island, between $24^{\text {th }}$ January and $12^{\text {th }}$ March 2012.

Fig. 2. Temperature on a rock surface outside the Bonner Laboratory at Rothera Research Station, Adelaide Island, between $5^{\text {th }}$ and $21^{\text {st }}$ February 2012.

Fig. 3. Mean percentage survival of $C$. antarcticus and A. antarcticus, following exposure to progressively higher temperatures (30 to $37^{\circ} \mathrm{C}-$ C. antarcticus, 30 to $40^{\circ} \mathrm{C}-$ A. antarcticus) for $1 \mathrm{~h}$, before cooling at $0.2^{\circ} \mathrm{C} \min ^{-1}$ to $4^{\circ} \mathrm{C}$. Means \pm S.E.M. are presented for three replicates of 10 individuals. Survival was assessed $72 \mathrm{~h}$ after treatment. Means with the same letter (A. antarcticus) and same number of * symbols (C. antarcticus) are not significantly different within each species group at $P<0.05$ (Kruskal-Wallis test and Tukey's multiple range test, respectively). A. antarcticus was not tested at 33 or $34^{\circ} \mathrm{C}$.

Fig. 4. Mean percentage survival of $C$. antarcticus and A. antarcticus, following direct exposure to progressively higher temperatures ( 30 to $36^{\circ} \mathrm{C}$ for C. antarcticus and 36 to $40^{\circ} \mathrm{C}$ for A. antarcticus) for 1 $\mathrm{h}$, before cooling at $0.2^{\circ} \mathrm{C} \mathrm{min}^{-1}$ to $4^{\circ} \mathrm{C}$. Means \pm S.E.M. are presented for three replicates of 10 individuals. Survival was assessed $72 \mathrm{~h}$ after treatment. Means with the same letter (A. antarcticus) and same number of * symbols (C. antarcticus) are not significantly different within each species group at $P$ $<0.05$ (Kruskal-Wallis test).

Fig. 5. Mean percentage survival of $C$. antarcticus and A. antarcticus, following exposure to the discriminating temperature $\left(35^{\circ} \mathrm{C}-\mathrm{C}\right.$. antarcticus, $39.5^{\circ} \mathrm{C}-\mathrm{A}$. antarcticus) for $1 \mathrm{~h}$, after being warmed to the discriminating temperature at one of three rates $\left(0.5,0.2\right.$ or $\left.0.1^{\circ} \mathrm{C} \mathrm{min}^{-1}\right)$. Means \pm S.E.M. are presented for three replicates of 10 individuals. Survival was assessed $72 \mathrm{~h}$ after treatment. Means with the same letter (A. antarcticus) and same number of * symbols (C. antarcticus) are not significantly different within each species group at $P<0.05$ (Tukey's multiple range test).

Fig. 6. Mean percentage survival of $C$. antarcticus and $A$. antarcticus at +4 and $+10^{\circ} \mathrm{C}$ over a period of 46 (C. antarcticus) and $49 \mathrm{~d}$ (A. antarcticus). Means \pm S.E.M. are presented for five replicates of 10 individuals. Means with the same letter (A. antarcticus) and same number of * symbols (C. antarcticus) are not significantly different within each species group at $P<0.05$ (Kruskal-Wallis test).

Fig. 7. Mean percentage survival of C. antarcticus and A. antarcticus following exposure to $40^{\circ} \mathrm{C}$ for 5 , 10 or $20 \mathrm{~min}$. Means \pm S.E.M. are presented for three replicates of 10 individuals. Survival was assessed $72 \mathrm{~h}$ after treatment. Means with the same letter (A. antarcticus) and same number of $*$ symbols $(C$. antarcticus) are not significantly different within each species group at $P<0.05$ (Kruskal-Wallis test).

Fig. 8. Mean percentage survival, following exposure to 33,34 and $35^{\circ} \mathrm{C}-\mathrm{C}$. antarcticus, and 39, 39.5 and $40^{\circ} \mathrm{C}-A$. antarcticus) for $1 \mathrm{~h}$, before cooling at $0.2^{\circ} \mathrm{C} \min ^{-1}$ to $4^{\circ} \mathrm{C}$. Both species were held at $10^{\circ} \mathrm{C}$ for one week prior to experimentation. Means \pm S.E.M. are presented for three replicates of 10 individuals. Survival was assessed $72 \mathrm{~h}$ after treatment. Means with the same letter (A. antarcticus) and same number of * symbols (C. antarcticus) are not significantly different within each species group at $P$ $<0.05$ (Tukey's multiple range test). 
Table 1. Mean percentage water loss of $C$. antarcticus and A. antarcticus, following exposure to 30, 35 and $40^{\circ} \mathrm{C}$ for $1 \mathrm{~h}$, prior to cooling at $0.2^{\circ} \mathrm{C} \min ^{-1}$ to $4^{\circ} \mathrm{C}$. Water content of control sample held at $4^{\circ} \mathrm{C}$ for 1 $\mathrm{h}$ also given. Means \pm S.E.M. are presented for five replicates of 10 individuals. 


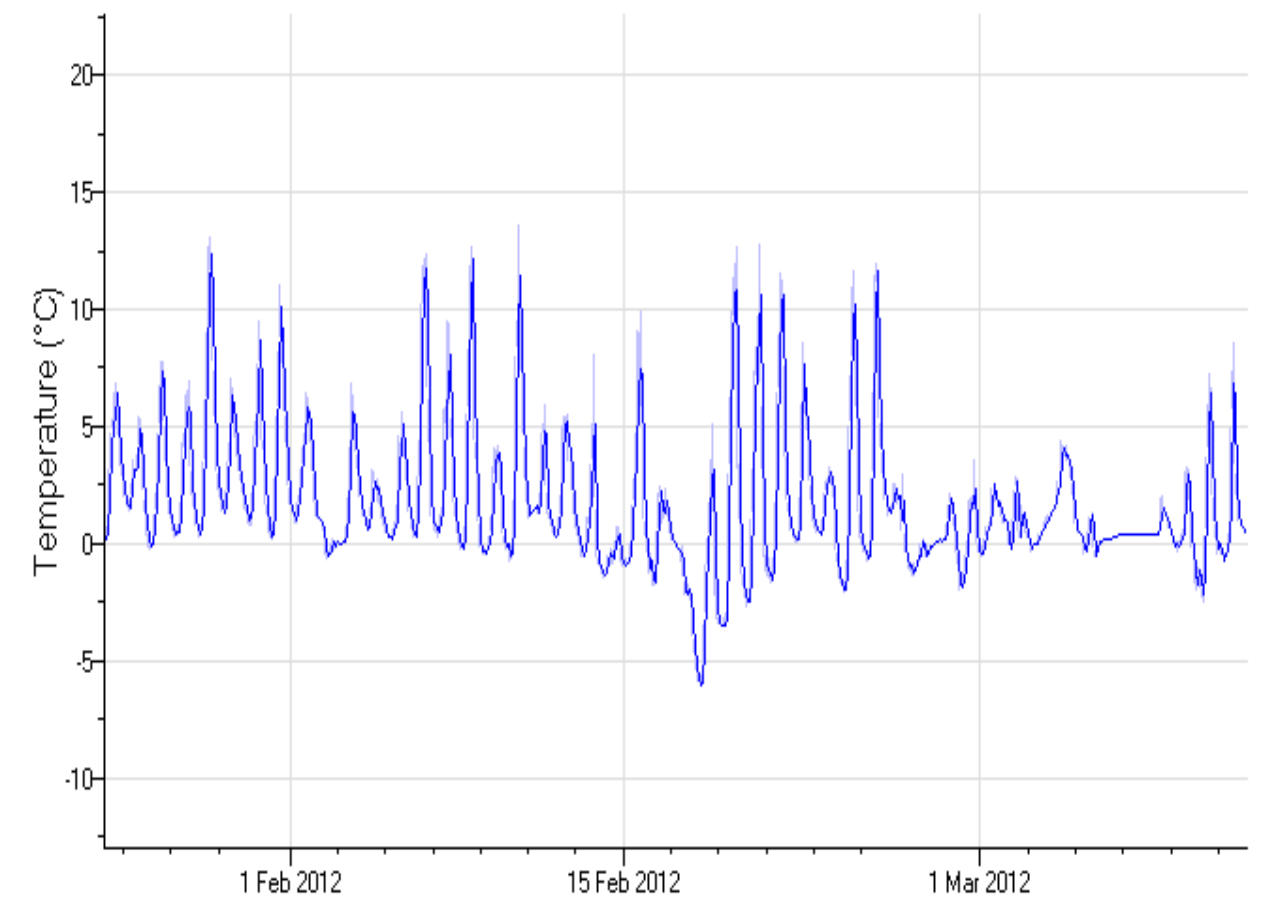

Figure 1 


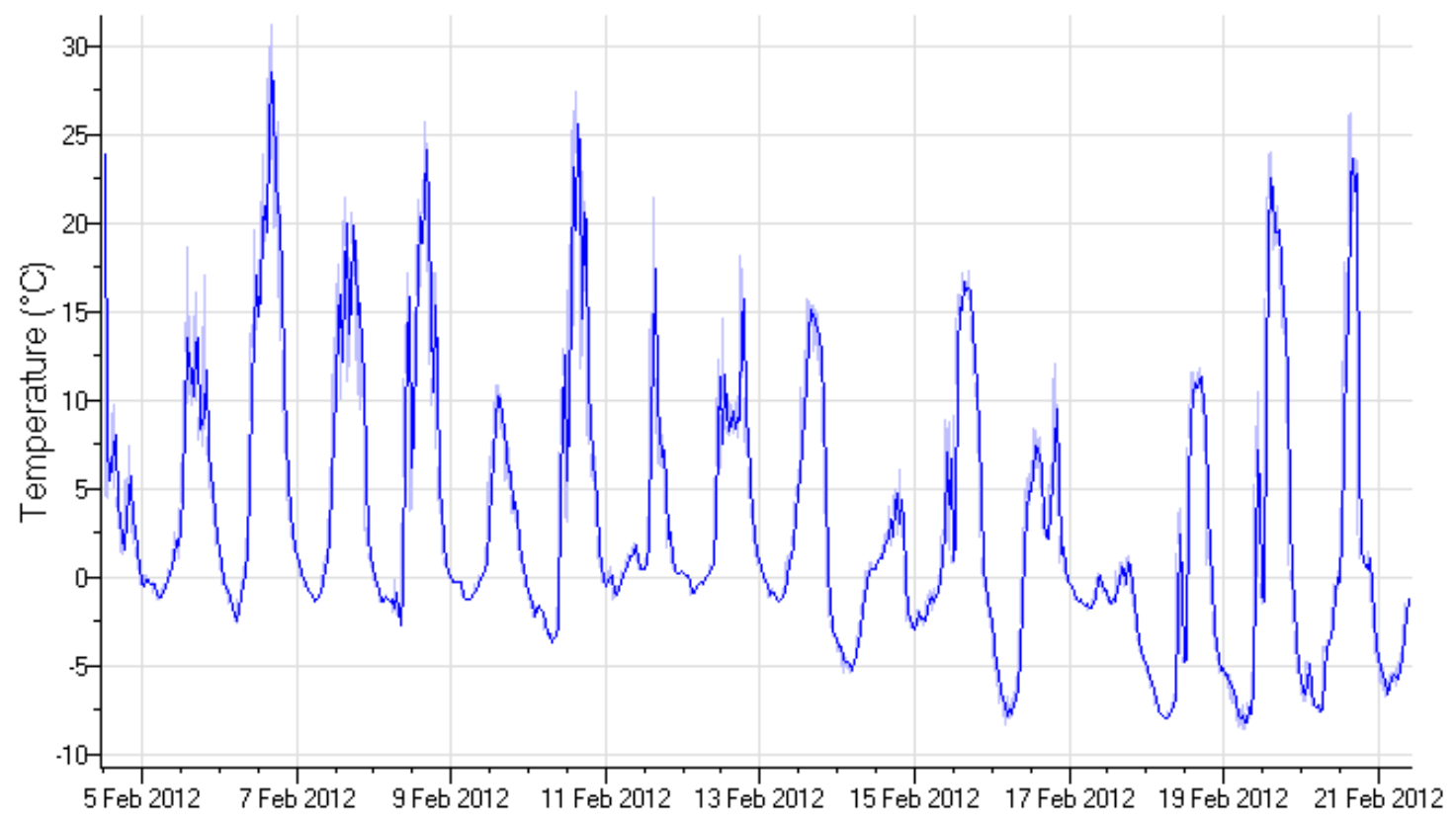

Figure 2 


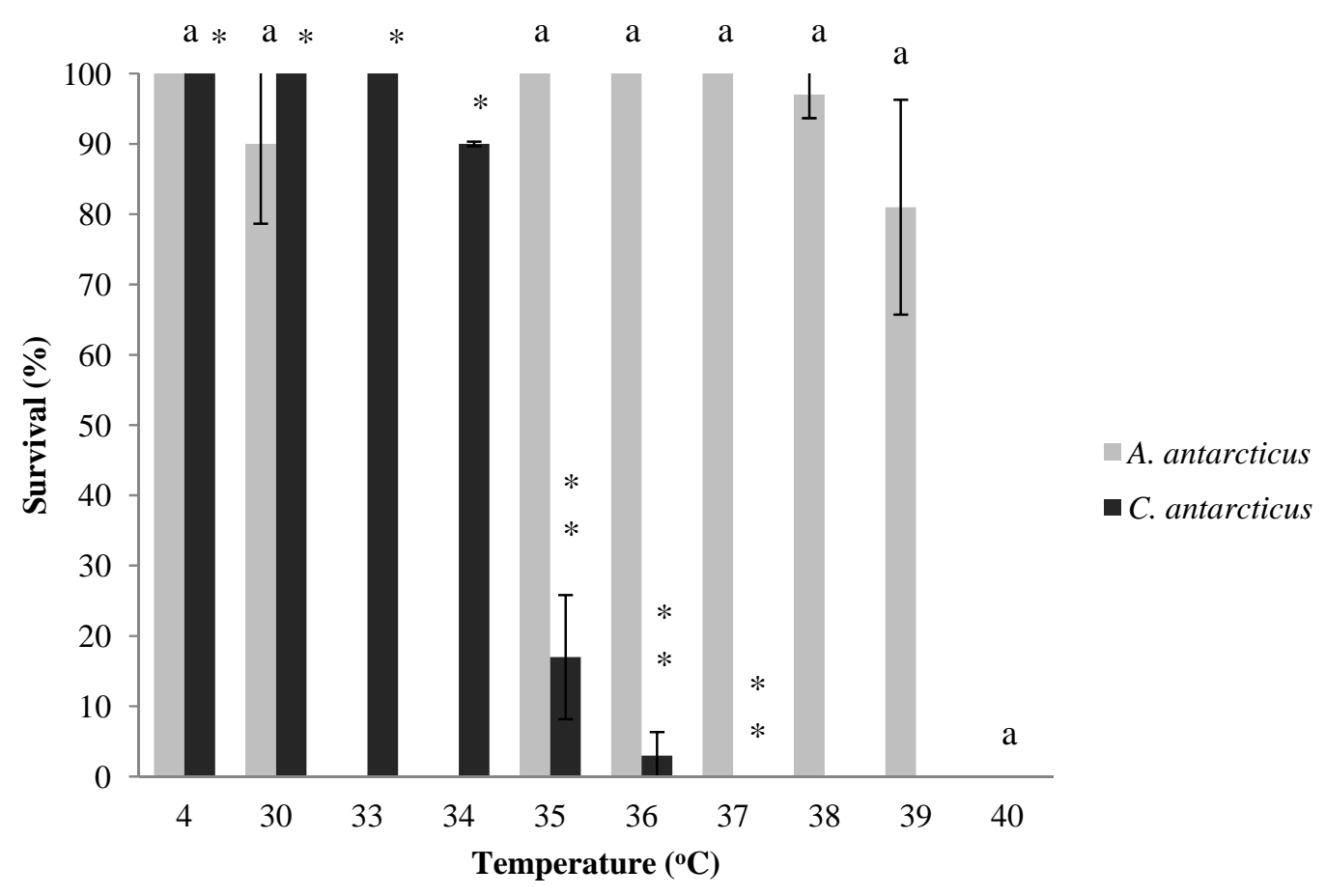




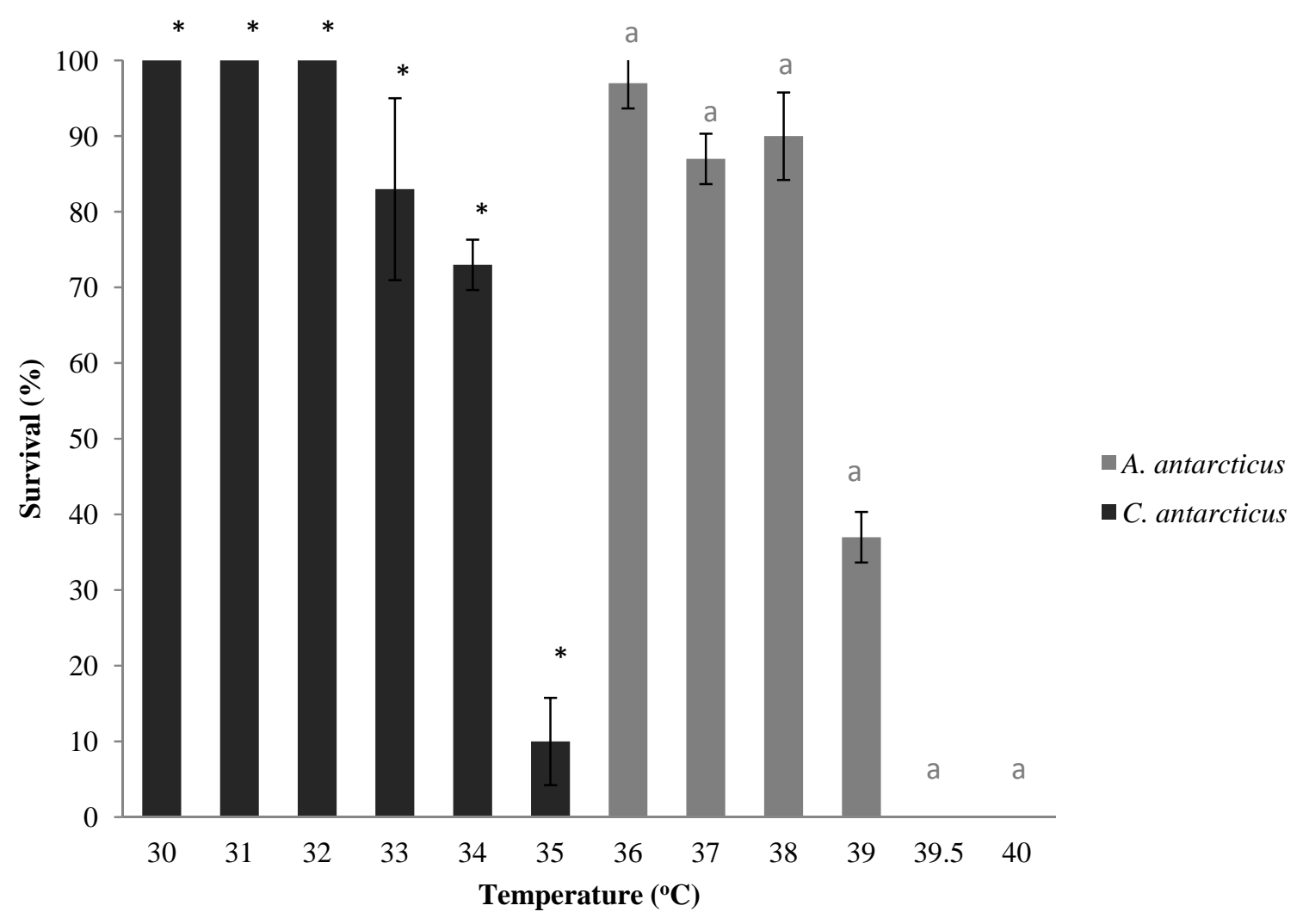

Figure 4 


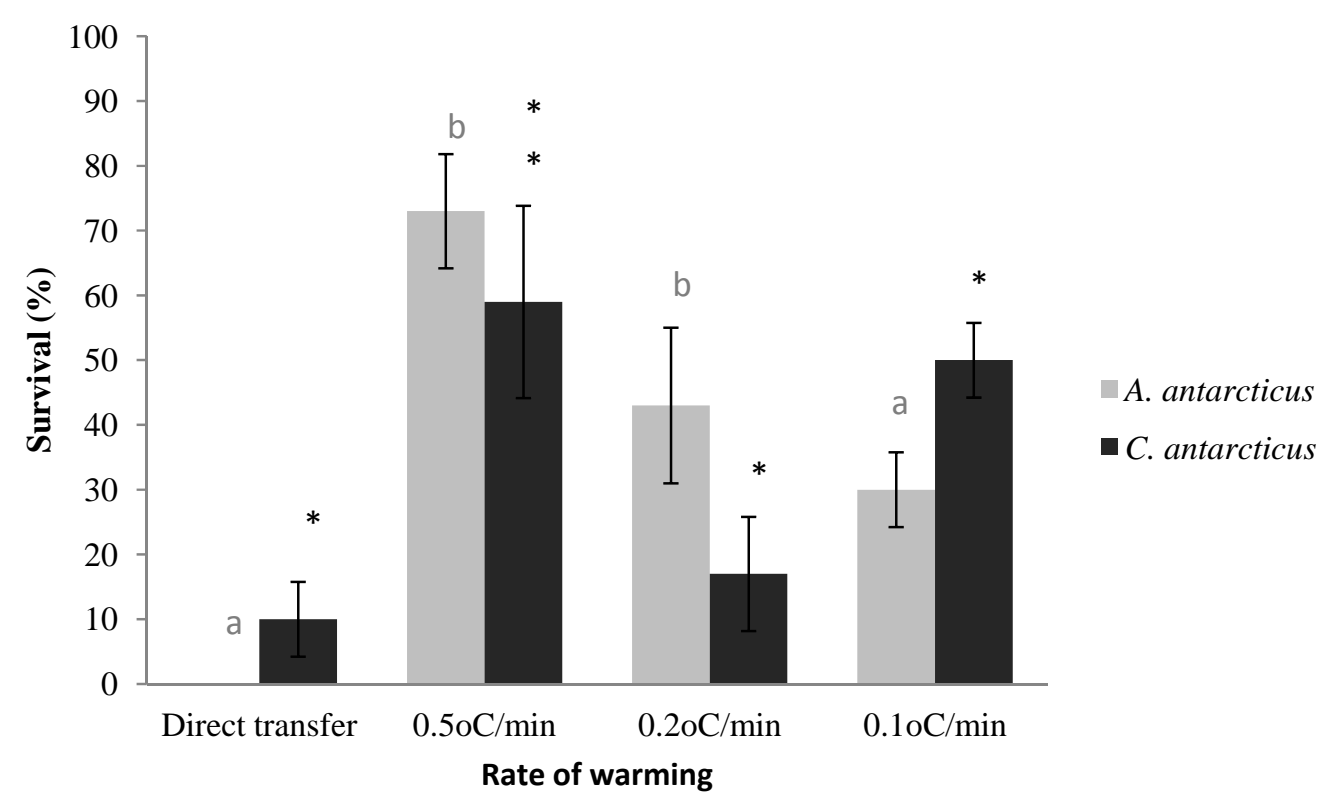

Figure 5 

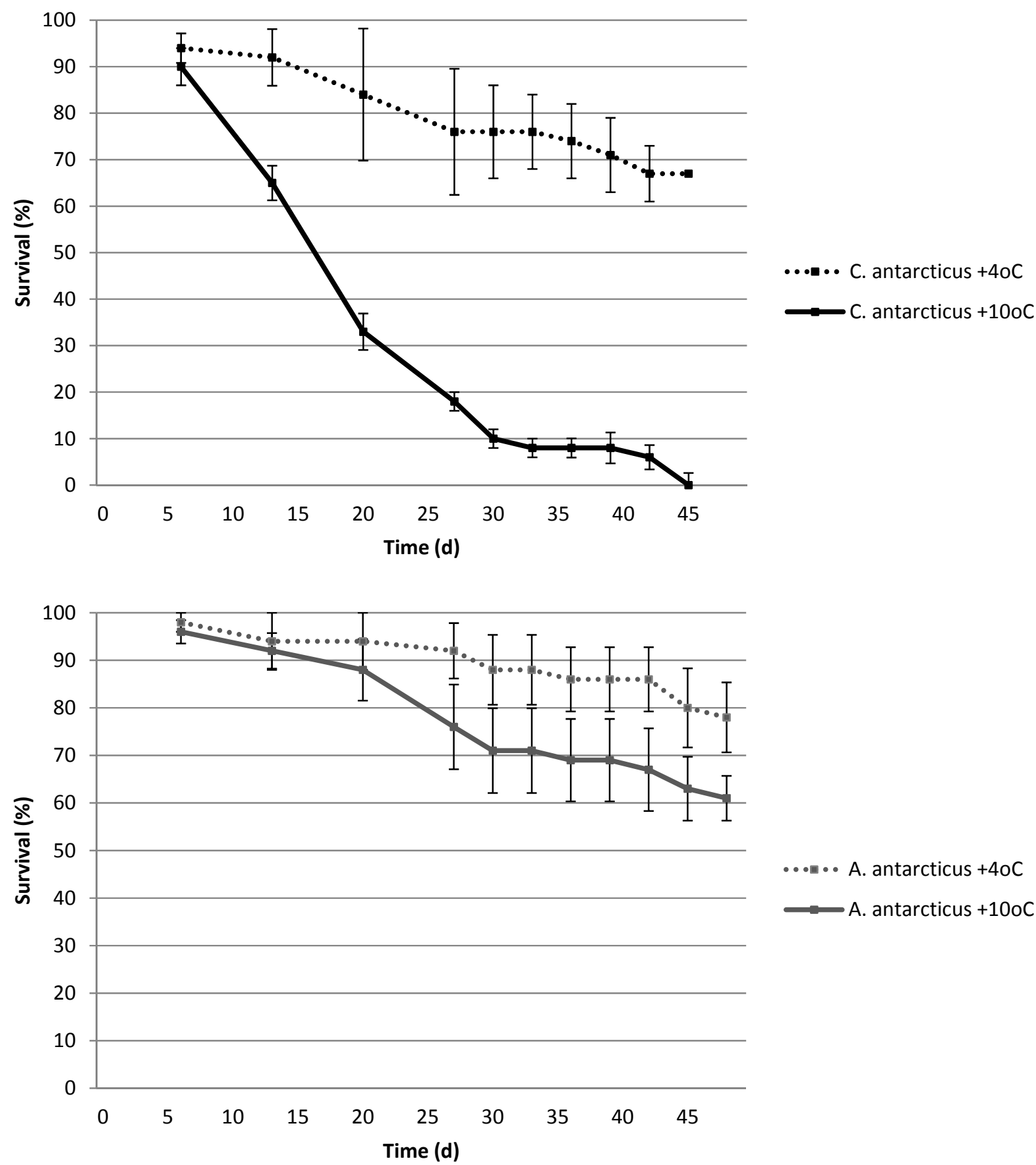

A. antarcticus $+40 \mathrm{C}$

A. antarcticus $+10 \circ C$

Figure 6 


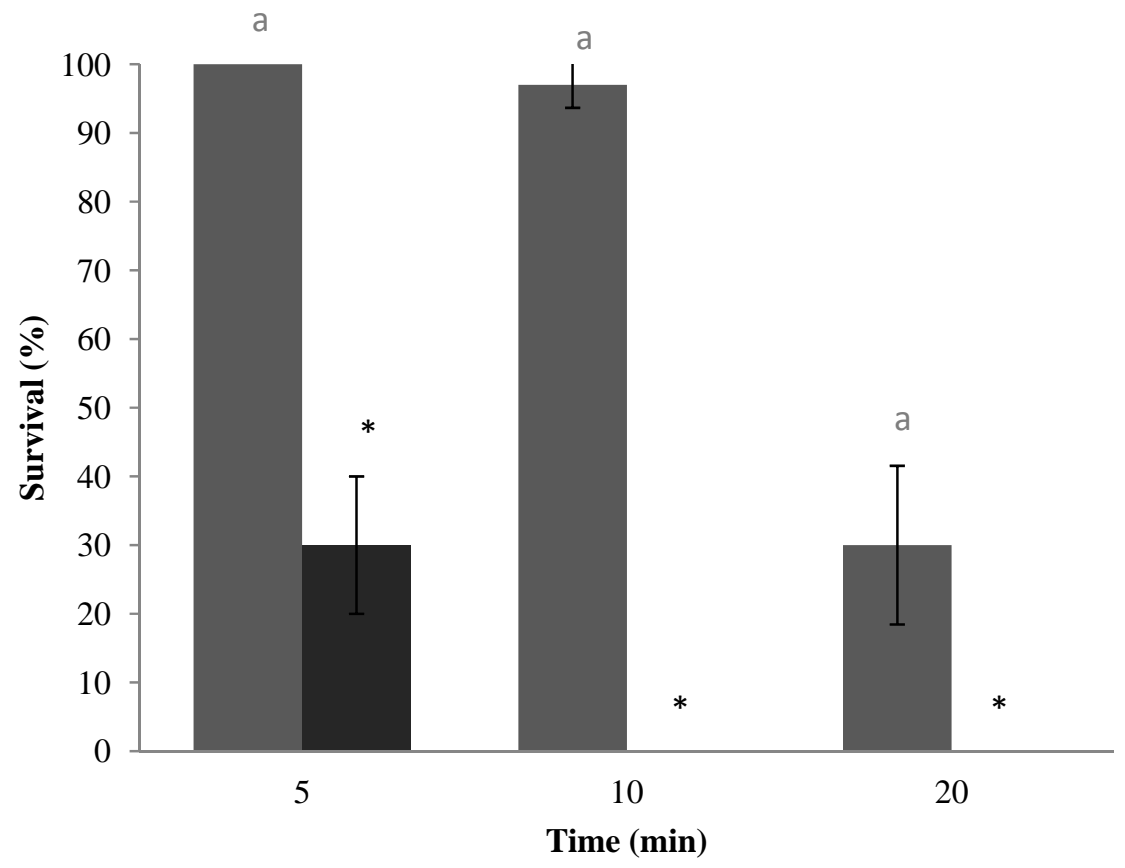

- A. antarcticus

- C. antarcticus

Figure 7 


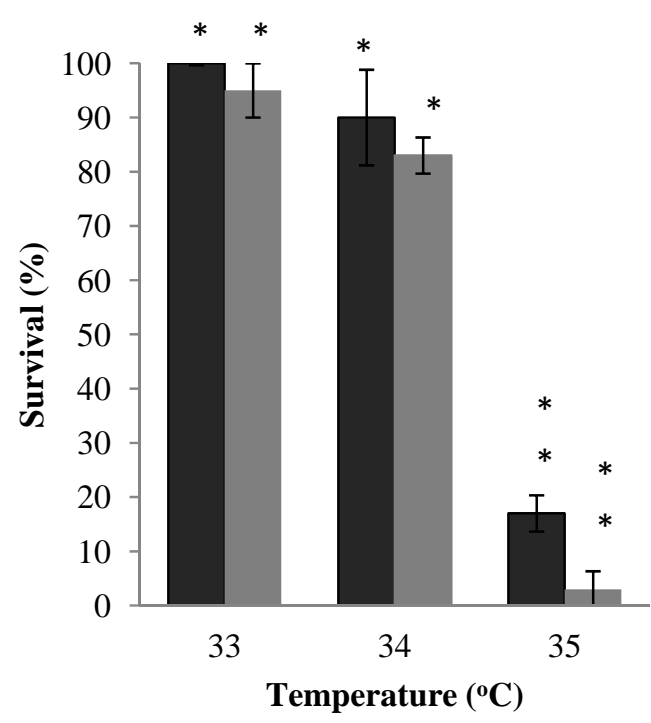

C. antarcticus nonacclimated

- C. antarcticus acclimated

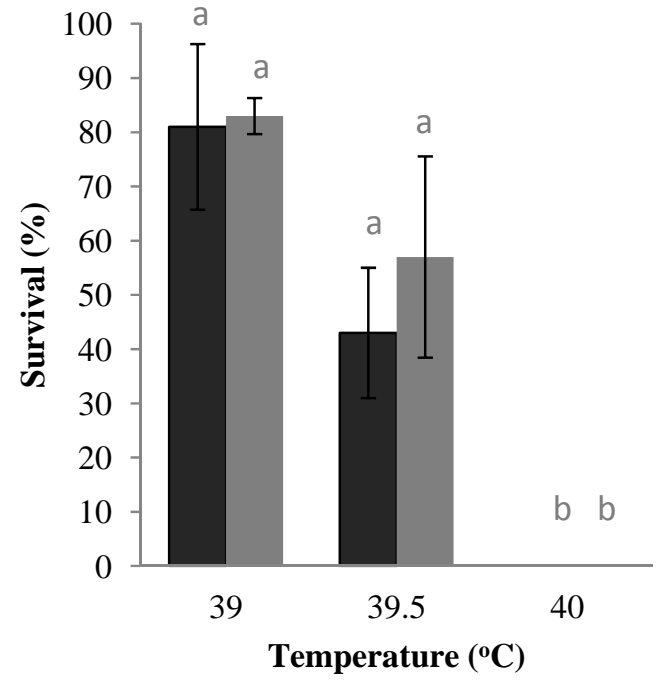

A. antarcticus nonacclimated

A. antarcticus acclimated

Figure 8 
Table

\begin{tabular}{|c|c|c|}
\hline \multirow{2}{*}{ Temperature $\left(\mathbf{~}^{\mathbf{C}} \mathbf{C}\right)$} & \multicolumn{2}{|c|}{ Water Content change (\%) } \\
\cline { 2 - 3 } & C. antarcticus & A. antarcticus \\
\hline $\mathbf{4}$ & $3.19 \pm 2.86$ & $-0.02 \pm 1.82$ \\
\hline $\mathbf{3 0}$ & $-1.58 \pm 1.76$ & $0.12 \pm 0.38$ \\
\hline $\mathbf{3 5}$ & $0.88 \pm 3.65$ & $-3.82 \pm 1.61$ \\
\hline $\mathbf{4 0}$ & $-6.68 \pm 0.81$ & $-2.08 \pm 0.45$ \\
\hline
\end{tabular}

Table 1 